\title{
Pesantren sebagai situs kewarganegaraan dan pembentukan budaya kewargaan di Madura
}

\author{
Ahmad Muwafiq dan Samsuri \\ Universitas Negeri Yogyakarta \\ waffiqnaamalsolih@gmail.com
}

\begin{abstract}
This research aimed to analyze the pesantren as a site of citizenship and its role in shaping civic culture in Madura. This research was qualitative with a case study The results of this study indicate that: 1) Pesantren as a site of citizenship was a place of sowing identity and spirit of religion and nationality for citizens who are participative, active, caring, sensitive and responsible. 2) The role of pesantren as a site of citizenship in shaping civic culture in Madura, appears in the field of education, social, and politics through the inculcation of religious and national values, community empowerment, and political involvement. All of that were voiced on the religious values that characterize pesantren as an institution of Islamic education. Pesantren with traditional managerial patterns was guided by an open and moderate religious understanding. In the pesantren with modern managerial patterns, the programs were based on Islami, Tarbawi, Ma'hadi, and Indonesiawi. The forms of overcoming the problem were the empowerment of alumni and cooperation with the community.
\end{abstract}

Keywords: pesantren, site of citizenship, civic culture

\section{Pendahuluan}

Pesantren sebagai lembaga pendidikan, termasuk salah satu jenis lembaga pendidikan Islam yang "indigenous" Indonesia. Sejak awal, pesantren bertujuan untuk mendalami ilmu-ilmu agama Islam dan mengamalkannya sebagai pedoman keseharian, atau disebut tafaqquh fiddin, dengan menekankan pentingnya moral dalam hidup bermasyarakat. Perwujudan dari tujuan pesantren itu diakui oleh banyak kalangan, bahwa pesantren telah ikut serta dalam mencerdaskan kehidupan bangsa dan sangat berjasa bagi umat Islam pada masa kolonial, karena tidak sedikit pemimpin bangsa terutama dari angkatan 1945 adalah alumni atau setidak-tidaknya pernah belajar di pesantren (Mastuhu, 1994, p. 3).

Ciri khas yang menjadi kepribadian pesantren adalah sebagai tempat pendidikan keagamaan. Pengajaran agama Islam di pondok pesantren merupakan tradisi luhur di Indonesia (Van Bruinessen, 1992, p. 73). Bahkan tradisi-tradisi keagamaan yang dimiliki pesantren sebenarnya merupakan ciri khusus yang harus dipertahankan (Madjid, 1997, p. 5). Hal ini juga tercermin dari tujuan utama pesantren untuk mencetak kader ulama yang mumpuni dalam bidang agama dan mampu menjalankan serta mengembangkannya dalam (Rusdi, 2007, p. 232). Namun di awal kemerdekaan, pendukung pendidikan kolonial menyebut pesantren sebagai sekolah tradisional, antiintelektualisme dan tidak sesuai dengan perkembangan zaman (Baso, 2012, p. 32). Pesantren sebagai tempat pendidikan keagamaan sempat menjadi perbincangan bahkan mendapat perhatian secara khusus. Terutama setelah terjadinya beberapa tindakan radikal yang mengatasnamakan agama. Hal ini sebagaimana diungkap oleh Robert W. Hefner (Hefner, 2009, p. 1) bahwa "Since the 9/11 attacks in the United States and the October 2002 Bali bombings in Indonesia, Islamic schools in Southeast Asia have been the focus of international attention.". Beberapa aktivis Islam garis keras 
kerap bertindak atas dalih agama sebagai bagian strategi untuk meminggirkan dan memusnahkan bentuk-bentuk pengamalan Islam toleran di berbagai belahan dunia, khususnya dunia Muslim. Tudingan bahwa pesantren menjadi rahim yang melahirkan radikalisme tak terelakkan lagi. Dari hasil pengamatan Sulasman (2015, p. 172) membenarkan hal ini, bahwa "keberislaman diri dan kelompok mereka adalah keberislaman yang paling benar, sementara yang lain dianggap memiliki kekurangan atau bahkan 'salah"'. Pola gerakan para aktivis Islam garis keras ini salah satunya adalah senantiasa berupaya dan berjuang untuk mengubah Islam sebagai agama menjadi sebuah ideologi. Upaya tersebut kemudian melahirkan sebuah sikap yang tertutup dan tidak mau menerima ideologi lain, bahkan siapa pun yang melawan ideologi mereka dituduh melawan Islam.

Tindakan dan upaya yang berujung pada tujuan untuk mendiskreditkan pesantren sebenarnya tidak terjadi pada akhir-akhir ini saja. Sejak era kolonial, Belanda dengan segala misi imperialistiknya, baik dalam bidang politik, ekonomi, budaya, dan bahkan agama, menganggap pesantren sebagai salah satu ancaman bagi tujuan-tujuan kolonialismenya. Berbagai upaya dilakukan untuk mendiskreditkan pesantren, salah satunya dengan memperkenalkan sistem pendidikan sekolah dan memperlakukannya sebagai anak emas, kemudian membuat stigma dan asumsi-asumsi negatif tentang pesantren (Jauhari, 2002, p. 6). Dampaknya, antara lain tercermin dalam sikap inferior, unconfident, inklusif, puritan, dependen, fanatik buta, serba apriori terhadap berbagai hal yang bersifat inovatif (Jauhari, 2002, p. 8). Jika ada pembaharuan dalam pesantren walaupun bentuknya sederhana, maka akan menimbulkan reaksi yang cukup hebat dari masyarakat sehingga sejumlah orang tua akan memindahkan anak-anaknya ke pesantren lain (Steenbrink, 1986, p. 71).

Di sisi yang lain, pesantren selain sebagai institusi pendidikan, juga merupakan institusi sosial keagamaan masyarakat Muslim Indonesia. Misi utama pesantren sebagai lembaga pengaderan calon-calon ulama tidak dapat ditawar-tawar dan tidak boleh diabaikan, namun pesantren juga tidak boleh melepaskan diri dari aneka persoalan aktual di tengah-tengah umat. Alumni pesantren dikenal sebagai sosok-sosok mandiri, giat, ulet, dan berdisiplin serta dibekali iman, takwa, dan akhlak mulia sehingga mampu memberikan pelayanan kepada masyarakat dan berpartisipasi dalam pembangunan masyarakat. Pada umumnya para alumni mengajar atau mendirikan lembaga-lembaga di tempat mereka menetap, dan tidak jarang berhasil dan berkembang menjadi besar atau menjadi manusia independen dengan jalan menjadi pengusaha, petani, maupun wiraswasta lainnya (Madjid, 1997, p. 98). Kontribusi pesantren di bidang sosial dan ekonomi sangat jelas. Atas dasar itu, sebagian peneliti menyebut pesantren sebagai agen pengembang masyarakat (agent of social development) (Djauhari, 2008, p. 89).

Melihat kenyataan bahwa pesantren juga ikut terlibat dalam kehidupan sosial politik di Indonesia merupakan penegasan bahwa identitas pesantren tidak lagi sekadar sebagai lembaga pendidikan. Hal ini dapat dilihat, misalnya adanya signifikansi antara dukungan kiai dan perolehan suara yang diperoleh sebuah partai politik. Selain itu, banyak lulusan pesantren yang terlibat secara aktif dalam perubahan politik secara nyata. $\mathrm{KH}$. Abdurrahman Wahid (Gus Dur) merupakan salah satu contoh dari tokoh pesantren yang 
berkiprah dalam politik. Dinamika politik di Indonesia mengantarkan Gus Dur menjadi presiden dan banyak berkontribusi dalam memperjuangkan demokratisasi di Indonesia (Turmudi, 2004, pp. 184-185). Hal itu merupakan bukti yang nyata dari pergeseran peran politik kiai pada tingkat politik yang lebih besar.

Peran pesantren di bidang sosial politik juga dapat dilihat sejak awal kemerdekaan. Pada waktu perang kemerdekaan, Pondok Pesantren Luhur Dondong Semarang dan Pesantren Suryalaya Tasikmalaya dijadikan sebagai markas TKR atas keputusan kiainya. Pada Pemilu 1955, Nahdlatul Ulama' (NU) yang didukung oleh sebagian besar kiai dan ulama tampil dalam jajaran empat partai politik terbesar di Indonesia saat itu. $\mathrm{KH}$ Hasyim Asy'ari membuat fatwa "wajib 'ain" bagi umat Islam Indonesia untuk mengangkat senjata melawan Belanda dari yang dikenal dengan sebutan "Resolusi Jihad". Peran KH Wahid Hasyim sebagai anggota Badan Penyelidik Usaha Persiapan Kemerdekaan Indonesia (BPUPKI) yang ikut terlibat dalam perumusan piagam Jakarta. Lahirnya keputusan politik Abah Anom atau KH Ahmad Shohibul Wafa Tajul 'Arifin untuk mendukung Sekber Golkar sejak awal berdirinya tahun 1963. K.H. Ahmad Siddiq mantan Rais Am PBNU pada pembukaan Mukatamar NU di Krapyak Yogyakarta tahun 1989 menegaskan keputusan NU untuk menerima Pancasila sebagai asas berbangsa dan bernegara. Kenyataan-kenyataan tersebut memperjelas keterlibatan pesantren beserta kiainya yang tidak hanya bergerak di wilayah pendidikan (Madjid, 1997, pp. 126-128).

Pada perkembangan berikutnya, berbagai pergulatan pemikiran keagamaan, tumbuh melalui transformasi nilai-nilai Islam yang khas bernuansa pesantren, atau paling tidak, tumbuh dari kalangan kaum santri yang dididik di pesantren. Pada posisi ini, pesantren tumbuh menjadi institusi penguat budaya nasionalisme dan berfungsi menjadi penguat akar budaya di tengah masyarakat yang heterogen. Istilah lain yang dapat digunakan untuk menggambarkan hal ini adalah bahwa pesantren selain berfungsi sebagai pemelihara budaya (cultural conserver), ia juga menjadi agen perubahan sosial (agent social of changes) (Horikoshi, 1987, p. 34).

Dhofier (2011, p. 76) membagi pesantren menjadi dua kategori yaitu pesantren salafi dan khalafi. Pesantren salafi merupakan model pesantren yang tetap mengajarkan pengajaran kitab-kitab Islam klasik sebagai inti pendidikannya. Penerapan sistem madrasah untuk memudahkan sistem sorogan yang dipakai dalam lembaga-lembaga pengajian bentuk lama, tanpa mengenalkan pengajaran pengetahuan umum. Pesantren khalafi telah memasukkan pelajaran-pelajaran umum dalam madrasah-madrasah yang dikembangkan atau membuka tipe-tipe sekolah umum di dalam lingkungan pesantren.

Menurut Horikoshi (1987, p. 34), setiap Pesantren selalu memiliki ciri khas yang berbeda satu dengan lain, meski tetap memiliki dampak yang kurang lebih sama dalam konteks bangunan umat dan bangsa Indonesia. Dari hasil pengamatan Azra (1999, p. 191), paling tidak pesantren memiliki tiga peran penting dalam konteks kebangsaan Indonesia. Ketiga peran dimaksud adalah: Lembaga yang mentransformasikan pengetahuan keislaman kepada masyarakat Muslim Indonesia; pemelihara tradisi Islam yang hampir jarang dimiliki lembaga keislaman lain di Indonesia, dan; pencetak para ulama, kiai atau mereka yang mengerti 
ajaran agama Islam untuk keberlangsungan Islam itu sendiri.

Keberadaan pesantren di Indonesia merupakan bagian tak terpisahkan dari kehidupan bangsa Indonesia. Artinya pesantren dan seluruh penghuninya sebagai bagian dari sistem kehidupan berbangsa dan bernegara. Pesantren sebagai komunitas yang terdiri atas kiai, ustad, dan santri juga merupakan bagian dari situs kewarganegaraan bangsa Indonesia. Oleh karena itu, maka pesantren mempunyai tanggung jawab untuk mempersiapkan santri-santrinya sebagai warga negara muda untuk menjadi warga negara yang baik di kemudian hari. Karena pesantren merupakan wahana paling strategis untuk membangun komitmen dalam rangka nation and character building khususnya kepada para peserta didik (santri) dan komponen pesantren lainnya (kiai, ustad, ustadah) sebagai warga negara. Artinya melalui pesantren, santri memiliki pengetahuan, sikap dan perilaku yang berlandaskan kepada nilai, norma dan moral sebagai warga negara.

Istilah "situs kewarganegaraan" merupakan gagasan yang tidak membicarakan soal tempat atau lokasi semata. Istilah tersebut muncul sejak adanya proyek pendidikan untuk kewarganegaraan demokratis yang dilaksanakan oleh Dewan Eropa. Konsep kewarganegaraan demokratis, sebagaimana yang dipahami oleh Dewan Eropa adalah tentang partisipasi yang lebih besar, kohesi sosial, akses, pemerataan, dan solidaritas (Starkey, 2002, p. 8)Untuk itu, kewarganegaraan demokratis lebih mengarah pada inklusi, partisipasi, budaya dan nilainilai, dan aktif dalam membentuk pemahaman dan praktik kewarganegaraan. Sedangkan bagi Audigier (Starkey, 2002), bahwa democratic citizenship has been described as a 'polysemous and contested concept'. At the core, however, citizenship 'is always a matter of belonging to a community, which entrains politics and rights'. Citizenship always has a political dimension, because citizens have the capacity to determine the law.

Situs yang dimaksud merupakan definisi ulang dari makna tempat, yang menunjukkan terjadinya praktik demokrasi. Situs terdiri dari setiap inisiatif (pusat, lembaga, komunitas, lingkungan, kota, wilayah, dll) adanya upaya untuk memberikan definisi dan melaksanakan prinsip-prinsip kewarganegaraan demokratis modern (Audigier, 2000, p. 25; Bîrzéa, 2000, p. 29).

Secara konseptual, seorang warganegara seyogianya memiliki lima ciri utama, yaitu: jati diri, kebebasan untuk menikmati hak tertentu, memenuhi kewajiban-kewajiban terkait, tingkat minat dan keterlibatan dalam urusan publik, tingkat dan pemilikan nilainilai dasar kemasyarakatan (J. J. Cogan, 1998). Kesemuanya disampaikan melalui bermacam institusi, baik pemerintahan maupun non pemerintahan.

Salah satu bentuk tidak lanjut dari proyek Education for Democratic Citizenship (EDC) adalah dilakukannya studi pada beberapa universitas. Dari hasil temuan selama studi yang dilakukan, Plantan mengungkapkan bahwa partisipasi mahasiswa di universitas ditandai dengan sikap pasif yang mengarah pada ketidakpedulian walaupun ada beberapa universitas yang aktif dalam membentuk kehidupan politik dan sosial masyarakat (Plantan, 2002, p. 13).

Penelitian ini dilakukan di Pesantren Annuqayah Guluk-Guluk, Sumenep, dan Pondok Pesantren Al-Amien Prenduan, Sumenep. Pondok Pesantren Annuqayah dapat disebut sebagai pesantren tertua di kawasan Madura bagian timur dan merupakan 
pondok pesantren yang mengusung konsep federasi dalam pola manajemennya, yakni Pondok Pesantren Annuqayah terdiri atas 18 pesantren daerah otonom. Sedangkan pondok pesantren Al-Amien Prenduan merupakan pondok pesantren yang mengusung konsep pondok pesantren dengan manajemen modern ala Pondok Modern Gontor sejak awal tahun 70-an. Eksistensi keduanya sebagai lembaga pendidikan Islam di Madura sampai saat ini masih tetap bertahan bahkan menunjukkan perkembangan ke arah yang lebih maju. Namun, potret tentang bagaimana pesantren dapat disebut sebagai situs kewarganegaraan dan bagaimana peranan kedua pesantren tersebut sebagai situs kewarganegaraan dalam membentuk budaya kewargaan di Madura masih belum diketahui.

Untuk itu, penelitian ini penting untuk dilakukan untuk mengungkap bagaimana pesantren sebagai situs kewarganegaraan dan pembentukan budaya kewargaan yang dilakukan oleh pondok pesantren sebagai situs kewarganegaraan di Madura. Harapan dari hasil temuan penelitian ini adalah dapat memberikan kontribusi teoretis guna pengembangan keilmuan Pendidikan Kewarganegaraan di Indonesia pada masamasa yang akan datang.

\section{Metode}

Penelitian ini merupakan penelitian kualitatif dengan pendekatan studi kasus berkaitan dengan peran pesantren sebagai situs kewarganegaraan dalam pembentukan budaya kewargaan pada masyarakat di Madura. Penelitian ini dilaksanakan sejak bulan Agustus sampai bulan Desember 2016. Penelitian ini dilaksanakan di Pondok Pesantren Annuqayah Guluk-Guluk Sumenep, dan Pondok Pesantren Al-Amien Prenduan Sumenep.
Peneliti mengumpulkan data secara mandiri dengan mempelajari dokumendokumen, mengamati perilaku, dan mewawancarai para informan (Creswell, 2015, p. 60). Untuk itu, peneliti menggunakan tiga teknik dalam mengumpulkan data-data yang dibutuhkan dalam penelitian ini, yaitu: observasi, wawancara, dan dokumentasi. Analisis data menggunakan analisis data induktif dan melaksanakan tiga kegiatan secara berurutan dari melakukan reduksi data, display/penyajian data, dan penarikan kesimpulan.

\section{Hasil dan Pembahasan}

Dilihat dari definisinya, konsep situs kewarganegaraan merupakan sebuah inisiatif pada tingkat lokal yang dibuat oleh komunitas, kelompok, lembaga sekolah, atau organisasi yang memungkinkan adanya inovasi untuk praktik kewarganegaraan yang demokratis yang mendorong partisipasi warga dalam kehidupan berbangsa dan bernegara. Praktik kewarganegaraan yang demokratis menjadi kunci pokok untuk menunjukkan ciri khas dari sebuah situs kewarganegaraan. Dengan demikian, harapannya adalah meningkatnya partisipasi warga negara dalam kehidupan berbangsa dan bernegara.

Pendidikan memainkan peran penting dalam pengembangan warga negara. Bîrzéa (2000, p. 40) mengungkapkan beberapa cara yang dapat dilakukan untuk meningkatkan lembaga yang demokratis dengan tingkat partisipasi yang tinggi, antara lain; mempromosikan Hak Asasi Manusia untuk pengembangan demokrasi, praktik demokrasi partisipatif, dan mengembangkan budaya organisasi yang demokratis. Mengadopsi konsep Bîrzéa tersebut, maka institusi seperti pesantren dapat dijadikan sebagai situs kewarganegaraan, yaitu sebagai tempattempat penyemai identitas dan semangat 
keagamaan dan kebangsaan untuk warga negara yang partisipatif, aktif, peduli, peka dan bertanggung jawab.

Ciri pokok tradisi pesantren sebagaimana diungkapkan oleh Kiai Zainuddin adalah mengajarkan dan menyebarkan Islam kepada masyarakat (Dhofier, 2011, p. 77). Selain itu, masih terdapat beberapa ciri khas pesantren yang dilakukan secara "tradisional", seperti hubungan akrab antara santri dengan kiai untuk mengambarkan suasana yang nyaman dan kondusif antara para santri dengan kiai tanpa mengurangi sikap dan rasa patuh terhadap perkataan kiai. Kepatuhan santri kepada kiai merupakan suatu kewajiban yang harus dijalankan. Sikap hidup hemat dan sederhana bertujuan untuk mengajarkan para santri agar senantiasa menggunakan segala sesuatu sesuai dengan kebutuhannya, tidak berlebihan dan agar para santri senantiasa bersyukur atas nikmat yang diterimanya.

Kehidupan di pesantren selalu mengajarkan pada para santrinya agar selalu berhati-hati dalam segala hal, karena santri diajarkan untuk menjalani hidup secara mandiri. Namun, kemandirian santri tidaklah dimaksudkan untuk memunculkan sikap individualistis, bahkan sangat erat dengan jiwa tolong menolong dan persaudaraan yang erat. Sanksi-sanksi dalam pesantren biasanya diterapkan dengan tujuan untuk menegakkan disiplin para santri. Biasanya sanksi yang diberikan bersifat edukatif sehingga menghasilkan efek positif bagi santri yang dikenakan sanksi.

Fungsi pesantren selama ini hanya diamati sebagai lembaga pendidikan agama. Di dalam konsep yang lain, pesantren adalah lembaga yang kondusif sebagai situs kewarganegaraan dengan potensi yang penting untuk adanya perubahan, yang dapat bertindak sebagai katalis untuk kehidupan masyarakat. Dari waktu ke waktu fungsi pondok pesantren berjalan secara dinamis mengikuti kondisi masyarakat global. Pesantren pada awalnya digunakan sebagai suatu wadah untuk menyiarkan agama, namun saat ini pesantren telah menyelenggarakan pendidikan formal maupun nonformal baik itu berupa sekolah umum maupun sekolah agama. Kiai sebagai aktor sekaligus kreator di pesantren cukup efektif sehingga pesantren dapat berperan sebagai perekat hubungan dan pengayom dalam kehidupan bermasyarakat. Dhofier (2011, p. 77) menerangkan bahwa kiai merupakan arsitek kemasyarakatan (social engineer) yang senantiasa memperhatikan "selera" masyarakat sehingga pesantren-pesantren mampu bertahan dan bahkan mengembangkan lembaga-lembaga pesantren untuk disesuaikan dengan kebutuhan kehidupan modern.

Penyesuaian terhadap "selera" masyarakat sebagaimana diungkap oleh Dhofier bukan berarti "pesantren, apa kata masyarakat." Penyesuaian tersebut diarahkan untuk mendidik masyarakat untuk dapat menyesuaikan diri dalam kehidupan yang modern. Melalui pendidikan dan programprogram pemberdayaan yang dilakukan pesantren kepada masyarakat, harapannya akan memunculkan rasa tanggung jawab yang pada berikutnya akan mendorong sikap partisipatif dari masyarakat, sehingga dapat memunculkan budaya kewargaan yang handal dalam kehidupan berbangsa dan bernegara.

Pondok Pesantren Annuqayah sebagai lembaga pendidikan Islam, tidak hanya fokus pada pendidikan keagamaan atau keislaman saja. Sebagaimana di jelaskan di atas bahwa Pondok Pesantren Annuqayah juga mengadopsi bentuk pendidikan modern dengan memasukkan ilmu umum, tetapi tetap mempertahankan dan memelihara betul-betul 
kurikulum dan bentuk-bentuk pendidikan salafiyah. Hal ini sejalan dengan ungkapan Florian Pohl (2009: 288) bahwa pesantren tidak hanya memperhatikan pendidikan Islam saja, pesantren juga melengkapi institusi pendidikan negara. Langkah tersebut mencerminkan sikap keterbukaan yang diambil sebagai bentuk khas yang akan membedakan sistem pengelolaan, cara pandang, dan keputusan untuk bertindak Pondok Pesantren Annuqayah dari pesantrenpesantren yang lain.

Selain itu, pengambilan sikap Pondok Pesantren Annuqayah sebagai pesantren yang menganut paham Ahlussunnah wal Jamaah sejak awal pendiriannya, menjadi sangat mudah diterima oleh masyarakat. Kegiatankegiatan yang dilakukan sangat jarang bahkan tidak bertentangan dengan kultur masyarakat Madura. Justru lebih banyak yang berkesesuaian dengan pola pikir masyarakat. Kalaupun tidak sesuai, maka Pondok Pesantren Annuqayah yang mengambil peran untuk meluruskan cara pandang masyarakat tersebut melalui berbagai bentuk penyadaran, bukan sebaliknya.

Sistem pengelolaan Pondok Pesantren Annuqayah menjadi ciri khas tersendiri yang unik, yaitu mengambil pola federasi dengan beberapa pesantren daerah yang memiliki hak otonom untuk melaksanakan kegiatan kepesantrenan di daerah. Istilah federasi ini sebagaimana diungkapkan oleh Mastuhu (1994, p. 74). Namun, masih ada kesepakatankesepakatan yang menjadi keputusan bersama untuk dilaksanakan secara bersama-sama pula. Hal ini tercermin dalam pengelolaan sistem pendidikan di Pondok Pesantren Annuqayah sendiri, selain mencerminkan sikap keterbukaan, tujuan pendidikan di Annuqayah memiliki tiga dimensi, yaitu dimensi agama, dimensi sosial, dan dimensi politik. Artinya, Pondok Pesantren Annuqayah menyadari posisi pesantren dalam kehidupan berbangsa dan bernegara. Selain memang Annuqayah ikut terlibat memperjuangkan kemerdekaan bangsa sehingga salah satu kiai Annuqayah gugur sebagai pahlawan.

Semangat perjuangan itu terus diwariskan pada generasi-generasi berikutnya. Bentuk perjuangannya mungkin sudah bukan kontak senjata lagi, akan tetapi memperjuangkan masyarakat agar semakin sejahtera. Program-program pemberdayaan masyarakat banyak dilakukan dan tidak sepenuhnya murni masalah perekonomian semata. Pondok Pesantren Annuqayah yang notabene nya merupakan lembaga pendidikan Islam, juga sekaligus melaksanakan fungsi dakwah dan pendidikan (Zakaria, 2010, p. 46). Sehingga respons masyarakat sangat positif sebagai bentuk dukungan atas program-program yang dilakukan. Namun tidak bisa dimungkiri, keterlibatan kiai secara langsung mempunyai pengaruh sangat besar dalam pembentukan budaya kewargaan. Hal ini dikarenakan kiai mempunyai gagasan yang fleksibel dengan kondisi kehidupan masyarakat sehingga Dhofier (2011, p. 77) menyebut kiai sebagai arsitek kemasyarakatan (social engineer).

Peran Pondok Pesantren Annuqayah dalam pembentukan budaya kewargaan di Sumenep Madura dilakukan melalui penanaman nilai-nilai keagamaan dan nilainilai kebangsaan pada masyarakat. Penanaman nilai-nilai tersebut dapat dilihat dari gerak aktivitas (amaliyah fiqhiyah) yang dilakukan oleh pesantren melalui proses pendidikan, pemberdayaan masyarakat, dan keterlibatan para kiai dalam dunia politik. Seluruh gerak aktivitas pesantren disemangati oleh dedikasi yang tinggi terhadap syiar 
agama Islam yang secara ideal ditujukan untuk meneguhkan sikap keagamaan (liyatafaqqahu fi ad-din) dalam arti yang seluas-luasnya. Tidak memaknai agama secara sempit dan tertutup sebagaimana beberapa organisasi keagamaan banyak bermunculan di beberapa tempat dalam beberapa tahun terakhir ini yang bahkan mengarah pada pemahaman keagamaan yang radikal. Pondok Pesantren Annuqayah melanjutkan apa yang diwariskan oleh K. Syarqawi sebagai implementasi dari prinsip "al-muhafazhatu 'ala al-qadimi al-shalih" dan terbuka terhadap perkembangan kekinian sebagai implementasi dari prinsip "wa alakhdzu bi al-jadiid al-ashlah".

Peran di bidang pendidikan tercermin dalam visi keilmuan yang menjelaskan bahwa Pondok Pesantren Annuqayah tidak mendikotomi ilmu menjadi "ilmu agama" dan "ilmu umum", tetapi semua ilmu adalah berasal dari Allah Swt. Dari visi keilmuan tersebut, dirumuskan pula tujuan pendidikan Pondok Pesantren Annuqayah yang memiliki tiga dimensi, yaitu dimensi agama, dimensi sosial, dan dimensi politik.

Pada dimensi agama, tujuannya adalah liyatafaqqahu fiddin (meneguhkan sikap keagamaan) dan menyebarkan agama Islam. Pada dimensi sosial tujuannya adalah untuk memberikan pengetahuan keagamaan dan berupaya memperbaiki kehidupan masyarakat dalam segala aspeknya. Pada dimensi politik, selain untuk melanjutkan semangat gerakan kemerdekaan melalui gerakan pendidikan, juga untuk mempersiapkan kepemimpinan umat Islam di masa depan. Dimensi agama merupakan landasan pokok dari tujuan seluruh bentuk pendidikan di Pondok Pesantren Annuqayah.

Program pemberdayaan dan pengembangan masyarakat menjadi salah satu peran yang menonjol dari aspek kepedulian sosial pesantren. Melalui peran pemberdayaan masyarakat ini, pesantren dan masyarakat diikat dalam bingkai kebersamaan dan keakraban. Masyarakat merasa memperoleh perlakuan baik dari pesantren dan merasakan hasilnya seperti usaha pengadaan air bersih, bantuan modal pertanian, pembebasan tanah-tanah dari para renten, bantuan pupuk, dan lain sebagainya, sehingga masyarakat secara swadaya juga membantu setiap kepentingan pesantren selain didukung oleh kuatnya kepercayaan masyarakat tradisional terhadap figur kiai. Pemberdayaan dan pengembangan masyarakat yang dilakukan oleh Pondok Pesantren Annuqayah merupakan bentuk da'wah bi al-hal (dakwah yang berorientasi pada tindakan) yang harus tumbuh dari nilainilai keislaman yang menyeluruh; Iman, Islam, dan Ihsan, yang meng-cover seluruh aspek kegiatan pengembangan yang diterapkan.

Peran di bidang politik ditunjukkan dengan keterlibatan para kiai Annuqayah yang terjun dalam dunia politik. Keterlibatan secara langsung dalam politik, menunjukkan adanya partisipasi yang tinggi. Keterlibatan para kiai dalam politik, tidak berpengaruh pada keberlangsungan pengelolaan pendidikan di lingkungan Pondok Pesantren Annuqayah. Perhatian terhadap pendidikan tetap menjadi prioritas Pondok Pesantren Annuqayah sebagai lembaga pendidikan di tengah keberagaman partai dan organisasi masyarakat (ormas) yang diikuti oleh para kiai Annuqayah

Peran-peran Pondok Pesantren Annuqayah yang tampak pada bidang pendidikan, sosial dan politik sejalan dengan pemaparan Bîrzéa terkait pengembangan warga negara melalui pendidikan yang 
menegaskan bahwa pendidikan memainkan peranan penting dalam pengembangan warga negara salah satunya dengan mempraktikkan secara langsung demokrasi partisipatif juga dengan mengembangkan budaya organisasi yang demokratis (2000, p. 40).

Untuk itu Pondok Pesantren Annuqayah dengan berbagai program pesantren yang tidak hanya memuat penanaman nilai-nilai keagamaan saja yang diberikan, tetapi nilainilai kebangsaan juga diberikan pada para santri, melakukan pemberdayaan kepada masyarakat, dan terlibat secara langsung dalam politik praktis melalui para kiai menunjukkan bahwa Pondok Pesantren Annuqayah melaksanakan peranannya yang positif sebagai situs kewarganegaraan. Respons positif masyarakat terhadap program-program pesantren yang ditunjukkan dengan tingkat partisipasi masyarakat yang tinggi dalam kegiatan-kegiatan yang digagas oleh pesantren, menunjukkan keberhasilan dari upaya Pondok Pesantren Annuqayah membentuk budaya kewargaan di masyarakat Sumenep Madura.

Secara internal, hambatan yang dirasakan oleh Pondok Pesantren Annuqayah dalam melakukan proses pembentukan budaya kewargaan adalah krisis kader. Sikap pragmatis santri dan wali santri merupakan pemicunya. Sikap pragmatis santri ditunjukkan dengan berbagai bentuk pelanggaran terhadap berbagai peraturan pesantren yang dilakukan santri mulai dari pelanggaran yang sifatnya ringan sampai pelanggaran berat. Sikap tergesa-gesa untuk segera lulus dan meninggalkan pesantren setelah lulus, juga dinilai pihak pesantren sebagai bagian dari bentuk sikap pragmatis santri.

Secara eksternal, Pondok Pesantren Annuqayah menghadapi tantangan pemahaman keagamaan yang cenderung tertutup di masyarakat. Kondisi ini menuntut Pondok Pesantren Annuqayah untuk senantiasa bersikap terbuka sekaligus peka terhadap keadaan. Kekhawatiran masuknya pemahaman keagamaan yang sempit, tertutup, bahkan cenderung radikal ke dalam pesantren, mulai dirasakan pihak pesantren dengan menyadari bahwa ada sebagian santri yang dalam menjalani proses mencari ilmu di Pondok Pesantren Annuqayah hanya sebentar saja. Artinya, nilai-nilai yang diajarkan di Pondok Pesantren Annuqayah belum terserap secara optimal, sehingga santri yang demikian dikhawatirkan akan mudah terpengaruh dengan pemahaman keagamaan yang sempit, tertutup, bahkan cenderung radikal tersebut.

Namun, dari penelusuran penelitian ini, belum ditemukan langkah yang pasti sebagai solusi alternatif untuk penyelesaian hambatan pembentukan budaya kewargaan oleh Pondok Pesantren Annuqayah. Pola pelaksanaan kegiatan masih tergantung pada ketokohan figur tertentu. Pribadi (2013, p. 7) menyebut bahwa pesantren merupakan lembaga yang dianggap sebagai milik kiai atau keluarga kiai, sehingga ketokohan figur kiai menjadi sangat dominan.

Langkah inisiatif yang dijalankan, baru merupakan langkah awal, yaitu dengan menghidupkan program koperasi yang masih belum dirasakan betul hasilnya guna penyelesaian hambatan-hambatan yang dihadapi. Pendidikan dan pemberdayaan masyarakat menjadi penting untuk terus dilakukan pihak pesantren agar kesadaran masyarakat dalam kehidupan berbangsa dan bernegara semakin terbuka dan semakin dewasa.

Konsep pesantren modern yang digunakan oleh Pondok Pesantren Al-Amien Prenduan, sedikit banyak merupakan adopsi 
dari sistem Pondok Modern Gontor, yakni manajemen kepemimpinannya menggunakan sistem yayasan yang berbadan hukum (Mastuhu, 1994, p. 74). Namun sudah disesuaikan dengan kondisi kehidupan masyarakat Madura. Hal ini merupakan tawaran tersendiri yang diajukan oleh pondok pesantren untuk masyarakat Madura. Konsepkonsep yang matang dan terencana bahkan terdokumentasi dengan rapi, menjadikannya semakin eksis, semakin kuat, dan semakin dewasa menghadapi berbagai dinamika kehidupan. Respons masyarakat tidak lagi hanya lingkup Madura saja, sampai tingkat nasional bahkan manca negara.

Kuncinya pembudayaan hidup yang menjadi konsep yang mapan dalam proses pembentukan budaya kewargaan pada masyarakat Madura. Melalui pembudayaan hidup yang demikian, Pondok Pesantren AlAmien Prenduan melahirkan generasi yang tangguh, siap juang, dan memiliki kemampuan serta keterampilan dalam berbagai aspek kehidupan sehingga mampu melahirkan prestasi-prestasi hidup yang bermakna dan bermanfaat baik bagi dirinya sendiri maupun bagi orang lain, bagi agama, nusa, dan bangsa. Inilah ciri khas yang membedakan lembaga pendidikan model pesantren dibandingkan dengan lembaga pendidikan non pesantren. Pondok pesantren satu-satunya lembaga pendidikan yang memiliki unsur sistem paling lengkap (Hasan, 2014, p. 11)

Penanaman nilai-nilai positif yang diberikan dan diajarkan di pesantren menjadi pegangan kuat bagi santri maupun bagi para alumni. Nilai-nilai yang ditanamkan, terutama nilai-nilai yang berbasis pada nilai-nilai keagamaan seperti sikap khusyu' dan tawadlu' (rendah hati), tunduk dan patuh kepada Allah Swt, serta mengimplementasikan fungsi khalifah Allah di muka bumi yang dapat tercermin dalam sikap proaktif, inovatif dan kreatif. Santri diberikan penyadaran bahwa dirinya sebagai hamba Allah satu sisi dan sebagai wakil Allah dengan sikap eksploratif inovatif (cerdas dan terampil). Penanaman nilai-nilai tersebut dilakukan secara terus menerus melalui prinsip-prinsip keteladanan.

Sebagai bagian dari subsistem pendidikan nasional dan sebagai bagian dari bangsa Indonesia. Pondok Pesantren AlAmien tidak hanya menanamkan nilai-nilai keagamaan saja. Nilai-nilai kebangsaan juga ditanamkan kepada seluruh komponen pesantren terutama kepada para santri. Nilainilai patriotisme, cinta tanah air, dan prinsip hidup berdemokrasi ditanamkan sekaligus dipraktikkan melalui mekanisme yang terencana dan terkonsep dengan matang.

Prinsip keteladanan seluruh komponen pesantren, khususnya para kiai dan asatid dengan konsep uswah, syu'bah, dan da'wah, menjadi daya tarik tersendiri bagi pengelolaan Pondok Pesantren Al-Amien Prenduan. Praktik-praktik hidup berdemokrasi sangat terasa sehingga tidak melahirkan kultus individu, karena semuanya bisa saling mengisi dan berbagi sesuai dengan porsi dan kapasitas masing-masing. Kompetensi kepemimpinan menjadi faktor penting pada proses transformasi (Subahar, 2008). Penanaman nilai-nilai tersebut juga dirasakan oleh masyarakat sekitar pesantren, sehingga pembentukan budaya kewargaan lebih tampak dengan respons positif masyarakat atas program-program pesantren yang senantiasa diberikan dalam bentuk dukungan dan kerja sama. Hal ini menunjukkan bahwa Pondok Pesantren Al-Amien Prenduan sejatinya merupakan bagian dari situs kewarganegaraan, yakni menunjukkan 
terjadinya praktik demokrasi (Audigier, 2000, p. 25; Bîrzéa, 2000, p. 29).

Perhatian para pimpinan Pondok Pesantren Al-Amien Prenduan terhadap pentingnya pendidikan bagi generasi muda sangat tinggi, sehingga ada kesepakatan yang tidak tertulis untuk tidak terjun dalam hirukpikuk dunia politik praktis dengan harapan tetap istiqomah membina pesantren sebagai lembaga pendidikan. Ketidakterlibatan secara langsung dalam dunia politik bukan untuk menunjukkan sikap antipati pihak Pondok Pesantren Al-Amien Prenduan terhadap politik. Prinsip “athi'ullaha wa athi'urrasul wa ulil amri minkum" (ketaatan kepada Allah, ketaatan kepada rasul, dan kepada pemimpin) tetap menjadi pedoman yang cukup kuat. Untuk itu, sebagai bagian dari komponen warga negara, para pimpinan dan seluruh komponen Pondok Pesantren Al-Amien mempunyai hak untuk menyampaikan aspirasi, memberikan suara dalam pemilu, dan lain-lain.

Pola budaya politik yang dipraktikkan Pondok Pesantren Al-Amien Prenduan, menunjukkan tipe budaya politik campuran antara subjek dan partisipan atau lebih dikenal dengan tipe budaya politik subjek-partisipan (Almond, Verba, \& Simamora, 1990). Hal ini ditandai dengan kuatnya prinsip ketaatan kepada pemimpin (ulil amri) yang mewarnai gerak aktivitas pesantren dan di sisi yang lain, komunikasi politik dibangun oleh pihak pesantren melalui berbagai bentuk kegiatan disertai dengan penyampaian aspirasi baik secara lisan maupun tulisan.

Hambatan yang dihadapi Pondok Pesantren Al-Amien Prenduan dalam pembentukan budaya kewargaan secara internal, tampak pada sikap pragmatis santri yang ditunjukkan dengan beberapa bentuk pelanggaran terhadap aturan dan ketentuan pesantren. Selain itu, terkadang pengurus pesantren masih harus berhadapan dengan masalah santri yang tidak mau dipisahkan dengan santri-santri lain yang berasal dari satu daerah yang sama. Sikap fanatik santri terhadap daerah asalnya ini yang cenderung dapat memunculkan kelompok-kelompok santri (geng) yang memang dilarang di pesantren.

Pemahaman keagamaan yang cenderung radikal dan mulai tumbuh di kalangan masyarakat di sekitar pesantren, juga menjadi salah satu hambatan yang dihadapi dalam proses pembentukan budaya kewargaan oleh Pondok Pesantren Al-Amien Prenduan. Dari hasil identifikasi yang dilakukan oleh pihak Al-Amien, pihak yang lebih banyak terlibat dalam kelompok-kelompok dengan pemahaman keagamaan yang radikal tersebut adalah sebagian besar dari kalangan pemuda. Untuk itu, pihak pesantren merasa tertantang untuk turut ambil bagian dalam penyadaran dan pemahaman keagamaan di masyarakat.

Dewan Riasah atau Majelis Kiai yang merupakan badan tertinggi di lingkungan Pondok Pesantren Al-Amien Prenduan melalui budaya musyawarah dalam setiap pengambilan keputusan terkait masalah pokok sosial-keagamaan di sektor dakwah, pendidikan, kaderisasi, dan ekonomi pesantren, menjadikan Pondok Pesantren AlAmien Prenduan semakin tangguh dalam menghadapi berbagai tantangan dan hambatan yang dihadapi. Sikap tanggap dan respons yang cepat menjadikan setiap permasalahan dan hambatan yang dihadapi juga segera tertangani, termasuk dalam penyelesaian hambatan pembentukan budaya kewargaan pada masyarakat di Sumenep Madura.

Penyelesaian hambatan yang dihadapi Pondok Pesantren Al-Amien dalam 
pembentukan budaya kewargaan dapat dilakukan sendiri oleh Al-Amien. Untuk hambatan internal, selain penegakan aturan yang diberlakukan, juga melalui pembinaanpembinaan secara personal. Pelibatan orang tua dalam proses penyelesaian juga digunakan jika sudah sangat dibutuhkan, terutama bagi santri yang memang sangat sulit untuk diatur. Untuk penyelesaian hambatan eksternal, melalui pelibatan peran alumni yang mempunyai andil besar terhadap eksistensi pesantren atau melalui berbagai kerja sama dan keterlibatan Al-Amien dalam berbagai forum.

Proses-proses penyelesaian hambatan yang dihadapi dalam pembentukan budaya kewargaan oleh Pondok Pesantren Al-Amien Prenduan sedikit banyak menggambarkan praktik ideal dari karakteristik kewarganegaraan demokratis sebagaimana diungkapkan oleh Cogan dan Derricott (1998, p. 116) Karakteristik yang dipraktikkan tersebut di antaranya adalah memiliki kepekaan terhadap dan mempertahankan Hak Asasi Manusia dan mempunyai kemampuan menyelesaikan konflik dengan cara damai tanpa kekerasan.

\section{Simpulan}

Pesantren sebagai situs kewarganegaraan merupakan tempat penyemai identitas dan semangat keagamaan dan kebangsaan untuk warga negara yang partisipatif, aktif, peduli, peka dan bertanggung jawab. Peranan pesantren dalam pembentukan budaya kewargaan pada masyarakat Madura yang dilakukan oleh Pondok Pesantren Annuqayah dan Pondok Pesantren Al-Amien Prenduan sebagai situs kewarganegaraan, tampak pada tiga bidang; bidang pendidikan, bidang sosial, dan bidang politik. Pada bidang pendidikan, masing-masing pesantren melakukan penanaman nilai-nilai keagamaan dan nilai- nilai kebangsaan yang diterapkan dalam kurikulum pendidikan dan program-program kegiatan di masing-masing pesantren. Pada bidang sosial, lebih tampak pada programprogram pemberdayaan masyarakat. Pada bidang politik, secara institusional kedua lembaga tersebut tidak berafiliasi pada partai politik tertentu. Pondok Pesantren Annuqayah melalui kiai-kiainya, ikut berpartisipasi dalam beberapa partai politik yang berbeda. Untuk itu, maka keterlibatan Pondok Pesantren Annuqayah dalam dunia politik melalui kiaikiainya menunjukkan pola partisipan. Sedangkan Pondok Pesantren Al-Amien Prenduan, sama sekali tidak ambil bagian dalam kehidupan politik praktis, walaupun secara sadar mengakui keberadaan pemerintahan yang sah dan hanya melaksanakan hak dan kewajiban sebagai warga negara, seperti ikut menyuarakan aspirasi yang disampaikan melalui para elit politik secara lisan maupun tulisan dan memberikan suara pada pemilihan umum, sehingga dapat dikategorikan sebagai pola subjek-partisipan.

Terdapat perbedaan dalam penyelesaian hambatan yang dihadapi dalam pembentukan budaya kewargaan pada masyarakat di Sumenep Madura oleh kedua lembaga. Pondok Pesantren Annuqayah yang menggunakan sistem tradisional dalam pola manajerialnya, belum menemukan formula yang pasti dalam proses penyelesaian hambatan yang dihadapi. Sementara, Pondok Pesantren Al-Amien Prenduan yang menganut pola manajerial modern, lebih cepat tanggap dan memberikan respons yang cepat terhadap permasalahan dan hambatan yang dihadapi, sehingga dapat segera tertangani. Penyelesaian yang dilakukan melalui mekanisme musyawarah oleh pihak AlAmien sendiri atau melalui berbagai kerja 
sama dengan masyarakat dan keterlibatan AlAmien dalam berbagai forum.

\section{Daftar pustaka}

Almond, G. A., Verba, S., \& Simamora, S. (1990). Budaya politik: tingkah laku politik dan demokrasi di lima negara. Jakarta: Bumi Aksara.

Audigier, F. (2000). Basic concepts and core competencies for education for democratic citizenship. Strasbourg: Council of Europe.

Azra, A. (1999). Pendidikan Islam: tradisi dan modernisasi menuju milenium baru. Yogyakarta: Logos Wacana Ilmu.

Baso, A. (2012). Pesantren studies 2a; buku II: kosmopolitanisme peradaban kaum santri di masa kolonial; juz pertama: pesantren, jaringan pengetahuan dan karakter kosmopolitan-kebangsaannya (Vol. 28). Tangaerang Selatan: Pustaka Afid.

Bîrzéa, C. (2000). Education for democratic citizenship: a lifelong learning perspective. Project On "Education for Democratic Citizenship" (Vol. 21). Strasbourg.

Cogan, J., \& Derricott, R. (Eds.). (1998). Citizenship for the 21st century: an international perspective on education. London: Kogan Page.

Cogan, J. J. (1998). Citizenship Education for the 21st Century: setting the context. In J. J. Cogan \& R. Derricott (Eds.), Citizenship for the 21 st Century: An Introduction Perspectives on Education (pp. 1-20).

Creswell, J. W. (2015). Qualitatif inquiry \& research design: Choosing among five appoaches. (Lazuardi, Trans.). Yogyakarta: Pustaka Pelajar.

Dhofier, Z. (2011). Tradisi pesantren: Studi pandangan hidup kyai dan visinya mengenai masa depan Indonesia (Revision). LP3ES.

Djauhari, M. T. (2008). Masa depan pesantren agenda yang belum terselesaikan (Vol. 72). Jakarta: Taj Publishing.

Hasan, A. (2014). Zujaj, dari aswaja ke liberaldari salaf ke khalaf. Mojokerto: Insan Global.

Hefner, R. W. (2009). Making modern Muslims: the politics of Islamic education in Southeast Asia. University of Hawaii Press.
Horikoshi, H. (1987). Kyai dan perubahan sosial. (U. Basalim \& A. M. Sunwara, Trans.). Jakarta: Perhimpunan Pengembangan Pesantren dan Masyarakat.

Jauhari, M. I. (2002). Sistem Pendidikan Pesantren: Mungkinkah menjadi Sistem Pendidikan Nasional Alternatif. Sumenep: Penerbit Mutiara Al-Amien Printing.

Madjid, N. (1997). Bilik-bilik pesantren: sebuah potret perjalanan. Jakarta: Paramadina.

Mastuhu. (1994). Dinamika sistem pendidikan pesantren. Suatu kajian tentang unsur dan nilai sistem pendidikan pesantren. Jakarta: INIS.

Plantan, F. (2002). Universities as sites of citizenship and civic responsibility. Strasbourg: Council of Europe.

Pribadi, Y. (2013). Religious networks in Madura: pesantren, Nahdlatul Ulama, and kiai as the core of santri culture. Al-Jami 'ah: Journal of Islamic Studies, 51(1), 1. https://doi.org/10.14421/ajis.2013.511.1-32

Rusdi, M. (2007). Pendidikan Islam di Indonesia sebelum proklamasi kemerdekaan. Lentera Pendidikan, 10(2), 228-237.

Starkey, H. (2002). Democratic Cctizenship, languages, diversity and human rights. Strasbourg: Council of Europe.

Steenbrink, K. A. (1986). Pesantren, madrasah, sekolah: pendidikan Islam dalam kurun modern. Jakarta: LP3ES.

Subahar, A. . (2008). Pondok pesantren di Madura: studi tentang proses transformasi kepemimpinan akhir abad XX. UIN Sunan Kalijaga.

Sulasman. (2015). Peasceful jihad dan pendidikan deradikalisasi agama. Walisongo, 23(1), 151-176.

Turmudi, E. (2004). Perselingkuhan kiai dan kekuasaan. PT LKiS Pelangi Aksara.

Van Bruinessen, M. (1992). Pesantren dan kitab kuning: Pemeliharaan dan kesinambungan tradisi pesantren. Ulumul Quran, 3(4).

Zakaria, G. A. N. (2010). Pondok Pesantren: changes and its future. Journal of Islamic and Arabic Education, 2(2), 45-52. 